\title{
Erratum to: Adaptive matching pursuit with constrained total least squares
}

Tianyao Huang, Yimin Liu*, Huadong Meng and Xiqin Wang

After publication of our work [1], we noticed that equations (41) and (42) (in Appendix 1) were incorrect. This does not affect resulting equations. The correct equations are below:

$$
\begin{aligned}
& \tilde{\mathrm{B}}=\boldsymbol{\Phi}_{\Lambda}+\mathbf{G}\left(\mathbf{D}^{-1} \otimes \mathbf{I}_{|\Lambda|}\right)\left(\mathbf{I}_{|\Lambda| \times(M+|\Lambda|)} \hat{\mathbf{u}} \otimes \mathbf{I}_{|\Lambda|}\right), \\
& \mathbf{Q}_{j}=\left[\left[\left(\mathbf{R}_{1}\right)_{\{j\}}, \ldots,\left(\mathbf{R}_{|\Lambda|}\right)_{\{j\}}\right] \mathbf{D}^{-1}, 0_{M}\right], j \leq|\Lambda|,
\end{aligned}
$$

We would like to thank Prof. Orhan Arikan who informed us of the typos.

Received: 3 September 2015 Accepted: 3 September 2015

Published online: 14 September 2015

\section{References}

1. T Huang, Y Liu, H Meng, X Wang, Adaptive matching pursuit with

constrained total least squares. EURASIP J Adv Signal Process 2012,

76 (2012)

* Correspondence: yiminliu@tsinghua.edu.cn

Department of Electronic Engineering, Tsinghua University, Beijing, China

Submit your manuscript to a SpringerOpen ${ }^{\circ}$ journal and benefit from:

- Convenient online submission

- Rigorous peer review

- Immediate publication on acceptance

- Open access: articles freely available online

- High visibility within the field

- Retaining the copyright to your article

Submit your next manuscript at $\boldsymbol{\wedge}$ springeropen.com
照 Springer

(c) 2015 Huang et al. Open Access This article is distributed under the terms of the Creative Commons Attribution 4.0 International License (http://creativecommons.org/licenses/by/4.0/), which permits unrestricted use, distribution, and reproduction in any medium, provided you give appropriate credit to the original author(s) and the source, provide a link to the Creative Commons license, and indicate if changes were made. 